\title{
Değişen Medeniyet Paradigmalarına Ayna Tutan Bir Gözlemci: Mısırlı Yahya Hakkı
}

\section{An Observer Who Mirrors Changing Civilization Paradigms: Egyptian Yahya Haqqi}

\author{
Hüseyin Yazıcı \\ Fatih Sultan Mehmet Vakıf Üniversitesi, Türkiye \\ hyazic@fsm.edu.tr
}

Geliş Tarihi: 17 Şubat 2020 Kabul Tarihi: 24 Nisan 2020 Yayın Tarihi: 30 Temmuz 2020

Öz: Mısır'ın önemli edebi şahsiyetlerinden olan Yahya Hakkı, 1905 senesinde Kahire'de mütevazı bir evde Türk bir baba ile Arnavut bir annenin oğlu olarak dünyaya gelmiş ve 1992'de Kahire'de ölmüştür. Kahire Üniversitesi, Hukuk Fakültesi'nden mezun olduktan (1925) sonra çeşitli ülkelerde diplomat olarak görev yapmıştır. Bu çerçevede 1930-1934 yılları arasında İstanbul'da, 1951-1952 yılları arasında da Ankara'da Mısır elçiliğinde görev yapmıştır. İstanbul'da bulunduğu süre içinde basından çeviri yapabilecek ve basını takip edebilecek düzeyde Türkçe öğrenmiştir. Türkiye'de bulunduğu süre içinde birçok şehri ve köyü gezmiş ve buralarla ilgili izlenimler edinmiştir. Zikreyât Matviyye (saklı kalmış hatıralar) adlı eseri uzun yıllar gün yüzüne çıkamamış, nihayet 1993 senesinde yani ölümünden bir sene sonra kızı Neha Yahya Hakkı'nın gayretleriyle basılabilmiştir. Türkiye'de kaldığı süre içinde edindiği kültürel, sanatsal, sosyal, siyasal, ekonomik ve askeri izlenimlerini selis üslubuyla tarihe kaydetmiştir. Okuyucuya sundukları sadece nakil değil, gözlem ve tahlil eleğinden geçen yazılardır.

Anahtar Kelimeler: Yahya Hakkı, Zikreyât Matviyye, Dem‘a ve İbtisâme

Abstract: Yahya Hakkı who is one of remarkable literary figures of Egypt, was born as a son of an Albanian mother with a Turkish father in a modest house in Cairo in the year of 1905 and has died in Cairo in 1992. He served as diplomat in various countries after graduation from Faculty of Law, Cairo University. In this frame; he served in Istanbul in between the years of 1930-1934 as well as in the Egyptian embassy, Ankara in between the years of 1951-1952. He learned Turkish at a level to translate from the press and to follow the press in the time he was in Istanbul. He visited many cities and villages and then acquired impressions about those places in the time he was in Turkey. His work named Zikreyât Matviyye (memories that remained hidden) could not come to light for many years. Finally in the year of 1993, namely one year later from his death, it was able to be printed with the efforts of Neha Yahya Hakkl, his daughter. He recorded his cultural, art,

ORC-ID: H. YazıcI 0000-0002-2480-2572 
social, political, economic and military impressions that he acquired in the time he was in Istanbul to the history with the selis style. What he present to the reader is not only transfer but they are the articles that pass through the sieve of observation and analysis.

Keywords: Yahya Haqqi, Zikreyât Matviyye, Dem‘a ve ibtisâme

\section{1. İstanbul'a Gelmeden Önce Yazarın Bazı Değerlendirmeleri}

Yahya Hakkı Türk asıllı olmasına rağmen, yetiştiği evde çok az Türkçe konuşulmuştur. Kendi ifadelerine göre Türk dili, ailede çok uzun yaşamamış, Arapça'nın etkisiyle tamamen silinmiştir.

Yahya Hakkı'nın Mahmud Tahir Hakkı isminde bir amcası vardı. Balkan harbinin çıkışı sıralarında (1912) amcası bir gün başında beyaz bir fes olduğu halde eve gelir. O sıralarda Sırplar Türkiye ile savaş halindedir. Mısır, Sırbistan'dan kırmızı fes ithal ediyordu. Bazı Mısırlı vatandaşlar, Sırpları protesto etmek amacıyla onlardan ithal edilen kırmızı fes yerine beyaz fes kullanıyordu. Yahya Hakkı'nın amcası da beyaz fes giyerek bir anlamda Sırpları protesto ediyordu. Bu, Türkiye'nin yanında yer alarak Sırpların fesini boykot etmek anlamına geliyordu. Diğer taraftan ilkokul sıralarında Mısırlı öğrenciler, Enver Paşa gibi bazı Türk büyüklerini tanıyor ve onlara benzemeye çalışıyordu. Mısır'da bu dönemde genel olarak Türk yöneticilere değer veriliyor, yüceltiliyor ve Türk Devleti'ne Avrupa'da İslâm'ı savunan bir kale olarak bakılıyordu.

\section{2. İskenderiye'den İstanbul'a (1931)}

Yahya Hakkı, büyük bir iştiyakla görmeyi arzu ettiği Türkiye'ye gitmek üzere İskenderiye'den Ege veya İzmir adlı büyük bir gemiye biner ve dört gün sonra İstanbul'a varır. Yahya Hakkı'nın ailesi kendisine İstanbul'da ikamet etmekte olan bazı akrabalarının adreslerini verir. Hakkı, İstanbul'a geldikten sonra bütün bu akrabaları tek tek ziyaret eder. Yaklaşık dört sene İsmail Bey, eşi, büyük kızı Beyza ayrıca Beyan, Azime, Ahmet ve Mustafa'dan oluşan bir akrabasının yanında kalır.

Yahya Hakkı, İstanbul'da farklı bir dünya ile karşılaşır. Yüzyıllarca dünyada hâkimiyet sürdürmüş olan bir İmparatorluk çökmüş ve onun yerine her şeyi ile yeni, kendisinin de hakkında çok şey bilmediği bir devlet kurulmuştur.

Yahya Hakkı'nın ilk yaptığı şey Türkçe öğrenmeye başlamasıdır. "Lâtin harfleriyle olsa da Türkçe öğrenmeye başladığım için şanslıydım. Lâtin harfleriyle okumaya karar vermiştim. Böylece kendimi dünyanın en güzel ülkelerinde yaşar bulmuştum." (Hakkı, Zikreyât Matviyye, 1993: 64). 
Yahya Hakkı İstanbul'da bir süre kaldıktan sonra Pire ve İzmir'e geçer. İzmir'den tekrar İstanbul'a gitmek üzere Çanakkale Boğazı'nı kullanır. Burayı gemiye binen birinin görebileceği en güzel yer olarak tanıtır. "Burası gemiye binenin seyredebileceği en güzel ve en eşsiz yerdir." (Hakkı, Zikreyât Matviyye, 1993: 64).

Diğer taraftan boğazın güzelliğine hayran kalan Yahya Hakkı, "Buranın güzelliğini kimse bana sormasın" der. (Hakkı, Zikreyât Matviyye, 1993: 64).

Dünyanın gözünün üzerinde olduğu İstanbul; romanlara, hikâyelere ve şiirlere konu olan bu nadide şehir, yazarın da oldukça beğenisine mazhar olur. "Istanbul'da nereye gidersen git, güzel manzaralar, denizler, tepeler, kaynak suları; kıyılarda serpilmiş kahvehaneler ve her kahvehanede bir tür çalgıların çalındığını görürsün" diyerek beğenisini dile getirir. (Hakkı, Zikreyât Matviyye, 1993: 64).

Yahya Hakkı'nın İstanbul'da bulunduğu sıralarda Münir Nureddin Selçuk (1900-1981) dönemin en büyük şarkıcısıdır. Münir Nureddin'in Kahire'ye gidip geldiğini ve kraliyet ailesinin kendisini çok iyi tanıdığını söylemektedir. (Kocak, 2003: 130-137) Nitekim Selim Sezgin de Münir Nureddin'in Bilmediğimiz Tarafları adlı yazısında sanatçının hemen hemen her yıl eşi ve kızıyla birlikte Kahire'ye gittiğini, ona bütün doğunun hayran olduğunu belirtmektedir. (musikidergisi.net, 2019).

Yahya Hakkı, "Münir Nureddin'in müziği sunuş ve icra şeklini Mısır'daki durum ile karşılaştırdığımda son derece gelişmiş bir müzik olarak değerlendiriyordum" (Hakkı, Zikreyât Matviyye, 1993: 65) diyerek Mısır'ın bu konuda geri kaldığını ifade eder. Yine kendi ifadelerinden Kahire'de Münir Nureddin'in konserlerine katıldığını anlamaktayız. Bu konuda Yahya Hakkı'nın değerlendirmeleri şu şekildedir:

\footnotetext{
"Münir Nureddin'in konserinde konser başlamadan bana bir program verirler. Böylece ben sanatçının hangi şarkılarını dinleyeceğimi bilirim. Ancak Mısır'da Ümmü Gülsûm'un (1898-1975) konserine gidenler konserin başında onun hangi şarkıları söyleyeceğini bilemezler. Ümmü Gülsûm, şarkının ilk bölümünü okuduğunda duyguların okşandığına dair tezahüratlar hemen yükselir. Münir Nureddin ise üç bölümde şarkı söyler. Birinci bölüm klasik tarzda dört şarkıdan oluşur. Dört şarkı modern tarzda, dört şarkı da halk türküleri tazında olur. Bu karışım, insan farklı renkleri izlediği için çok güzeldi. Arkada da üç ya da enstrümantal vardı; Kanun, kemençe ve ney. Oysa Mısır'da böyle bir oluşum yoktu." (Hakkı, Zikreyât Matviyye, 1993: 65).
} 


\section{3. İstanbul'daki Kültürel ve Toplumsal Hayat}

Yahya Hakkı'nın ilk dikkatini çeken şey, bir İslâm devletinin nasıl laik bir devlete dönüştüğüdür. 1930'lu yıllar gibi henüz erken bir dönemde bu durumun yansımalarını daha iyi öğrenebilmek için Türkçe bilmek gerekiyordu. Yahya Hakkı da bir Türk aile ile oturmasının ve Türk diline ciddi bir şekilde eğilmesinin kendisi için bir şans olduğunu dile getiriyor. Bunun sonucunda da hem gazete hem Reşat Nuri Güntekin (1889-1956) gibi yazarların yazmış olduğu kısa öyküler hem bazı eski hikâyeleri okuyup anlayacak hale gelir. Türkiye'de meydana gelen gelişmeleri takip edebilmesi için belirli düzeyde Türkçe öğrenmesi gerekliliğine inandığı için bu meseleyi özel yeteneklerini de kullanarak çözer. Yahya Hakkı Türkçe'yi sadece öğrenmekle kalmaz, tiyatroya ve operaya da gitmeye başlar.

Bilindiği gibi çok fazla okunup tanınmış romanların yazarları o romanı tiyatro oyunu haline getirirler. Bizim edebiyatımızda da buna Reşat Nuri'yi ve onun Yaprak Dökümü adlı eserini örnek verebiliriz. Aslında bu gelenek dünya edebiyatlarına ve bize herhalde Fransız edebiyatından geçmiş olmalıdır.

Yahya Hakkı; annesi Kıptî, babası Keldânî olan Irak asıllı Mısırlı komedyen Necîb erReyhânî'ye (1889-1949) benzettiği tuluat sanatçısı "Sultan II. Abdülhamid'i güldüren adam" diye de tanınan Naşit Efendi'nin (1886-1943) komedi oyunlarını seyrettiğini söyler. (Hakkı, Zikreyât Matviyye, 1993: 66) Hatta Naşit Efendi'nin oynadığı bir Fransız oyununu Mısır'da Necib er-Reyhânî'nin de oynadığını söylemektedir. Gittiği tiyatroda bulunan insanları da anlatan Yahya Hakkı, o dönemde Türk tiyatrosunun gelişmiş olduğunu ancak her şeye rağmen doğu tiyatrolarına benzediğini söylemektedir. Yahya Hakkı ayrıca Türklerin Naşit Efendi'yi sadece oyunculuğuyla tanıdıklarını ona ne filozof ne de dâhî sıfatlarını vermediklerini söyler. Onun sadece büyük bir önemi haiz sanatçı olarak görüldüğünü ve bunun da yeterli olduğunu söyleyerek yazar, herhalde Mısır'da durumun böyle olmadığını ima etmek ister.

Diğer taraftan opera ve orkestraya da değinen Yahya Hakkı, boğazın kıyılarında bulunan eğlence mekânlarından da bahsetmektedir. Buralarda müzik çalındığını ve bu müzik eşliğinde erkeklerin el ele tutuşup oynadığını söylemekte ayrıca oynayanların durumunu sanki humma hastalığına yakalananlara benzetmektedir. Herhalde bu oyunlar, Karadeniz veya Çeçen oyunları olmalıdır.

Başta; Türk asıllı, son devir Arap şairlerinin en ünlü ve önemlisi Ahmet Şevki (18681932) olmak üzere pek çok Mısırının İstanbul'u ziyarete geldiğini söyleyen Yahya Hakkı, 
Arap şiirinden Türkçe'ye herhangi bir çevirinin yapılıp yapılmadığı konusunu araştırır. Ancak kitapçılarda bununla ilgili herhangi bir şey bulamaz. Diğer taraftan Türk şiirinden de Arapça'ya herhangi bir çeviriye rastlamadığını da belirtmektedir. (Hakkı, Zikreyât Matviyye, 1993: 68)

Yahya Hakkı, Ahmet Şevki'yi sadece Abdülhak Hamid Tarhan'ın (1852-1937) tanıdığını öğrenir ve bir toplantıda onunla tanışır. Abdülhak Hamid kendisine Şevkî̀yi çok kısa bir süreliğine gördüğünü ancak hakkında hiçbir şey okumadığını söyler. (Hakkı, Zikreyât Matviyye, 1993: 68-69)

Akif'ten de milli marşımız dolayısıyla bahseden Yahya Hakkı, Mustafa Kemal Atatürk'ün kendisine kızdığını ve bu yüzden Mısır'a sığındığını söyler. Bu arada Milli marşımızdan oldukça etkilendiğini ve marşın dinleyende garip bir his bıraktığını ifade eder. (Hakkı, Zikreyât Matviyye, 1993: 69)

Yahya Hakkı, kendisinin son derece hassas bir dönemde Türkiye'de bulunduğunu söyleyerek Türkiye'deki değişimi yani Türkiye'nin laisizme geçişini gözüyle gördüğünü, kulaklarıyla duyduğunu ve bu değişime eliyle dokunduğunu ifade eder.

Yahya Hakkı'nın milli marşımızla ilgili yapmış olduğu değerlendirmeden sonra kaleme aldığı aşağıdaki ifadeler son derece önemlidir: "Türkiye'de yapılmaya çalışılanlara rağmen ruhani hayat ve Dinî heyecan hiç bitmemiş, Türkler dinleriyle zenginleşmeye devam etmiş, eşsiz camiler gibi islami mimaride ilerlemeyi sürdürmüştür." (Hakkı, Zikreyât Matviyye, 1993: 71)

Yahya Hakkı, tarihi eserlerden bahsederken özellikle Ayasofya'nın üzerinde durur. "İslâmî Fetih" diye tanımladığı İstanbul'un fethinden hemen sonra kiliseden camiye dönüştürülen Ayasofya'nın Cumhuriyetin başlarında müzeye çevrildiğini söylemekte ve defalarca orayı ziyaret ettiğini belirtmektedir. (Hakkı, Zikreyât Matviyye, 1993: 70-71)

Ayasofya'nın güzelliğinden, çekiciliğinden bahseden Yahya Hakkı, buranın güzelliğinin, insicamının yakından değil ancak uzaktan görülebileceğini ifade eder.

\section{Ayasofya'da Kadir Gecesi Namazı}

"Çok soğuk bir geceydi. Bazıları ellerinde mangallarla gelmiş/erdi. Ben diplomatlara tahsis edilen yerdeydim. Neden diplomatlara ayrılan ayrıcalıklı yere oturdum ve yukarıya çıktım; benim aşağıya inip Türklerle aynı safta namaz kılmam gerekiyordu 
diyerek bu konuda kendimi ağır bir şekilde eleştirdim." (Hakkı, Zikreyât Matviyye, 1993: 71)

Yahya Hakkı'nın notlarına göre Ayasofya'nın önce kiliseye dönüştürülmek istendiğini ancak daha sonra yapılan uzun uzun münakaşalardan sonra orta bir yol olarak müzeye çevrilmesinin daha uygun olacağı kararına varıldığını söylemektedir. (Hakkı, Zikreyât Matviyye, 1993: 71) Müzeye çevrildikten sonra da duvarlardaki kaplamalar sökülmüş ve böylece Hristiyanlığa dair resimler ortaya çıkmış ancak Fatih Sultan Mehmet döneminde asılan Hz. Peygamberîn adı ile dört halifeye dair yazılar ise olduğu gibi bırakılmıştır.

Bu karardan sonra Ayasofya'da yapılmasına karar verilen değişiklikleri bizzat gören Yahya Hakkı duygularını şu şekilde dile getirmektedir:

\begin{abstract}
"Ayasofya'yı ziyaretim esnasında hissettiğim soğuk atmosferi hiçbir yerde hissetmedim. Burası ne bir kiliseye benziyor ne de camiye. Bu güzel binaya sıcaklık veren, ister kilise ister cami olsun namazdı, duaydı ve yakarışlardı. Işte Dinî mabetlerin sırrı burada yatmaktadır. Bu binalar dışardan görüldüğü gibi taş ve çimentodan ibaret değil, asıl olan içerdeki yakarışlardır." (Hakkı, Zikreyât Matviyye, 1993: 72)
\end{abstract}

Yazarın Türk insanı ile ilgili olarak yapmış olduğu bir değerlendirmesi oldukça dikkat çekicidir. "Bununla birlikte İstanbul halkı Kadir gecesini ihya etmek için Ayasofya'yı seçti. Bu gecede oraya gelmeyen Türklerin Islâm'a olan bağlılıklarını, Islâm'ın onlara etkisini anlayamayacaktır." (Hakkı, Dem'a ve İbtisâme, 1965: 26)

Bu arada Bayezid, Süleymaniye, Eyüp Sultan ve Fatih camilerinden de bahseden Yahya Hakkı, bu camilerin levhalarındaki nesih türü yazılara değinerek "Kur'ân Mekke'de indi, Kahire'de okundu, İstanbul'da yazıldr' (Hakkı, Zikreyât Matviyye, 1993: 72) sözünü de hatırlatmaktadır. İnsanın ruhunu okşayan bu yazıların kendisini bütün bu camilerde Cuma namazı kılmaya teşvik ettiğini söylemektedir. Ancak Cuma namazı için gittiği bir camide imamın hutbede söyledikleri Yahya Hakkı'yı son derece şaşırtır:

"Imam, hutbede temizlikten ve güzel koku sürünmekten bahsediyordu. Imam, 'Dinî tavsiyelere uyarak size güzel esanslar hazırladım. Namazdan sonra sizin bunlardan satın almanız için kapıda duracağım’ dedi. Ticaretle uğraşan bu imama çok şaşırmıştım." 
Türk Osmanlı Müzesi diye tanımladığı Topkapı müzesinden ayrıca Kahire'deki Hânü'lHalili çarşısına benzettiği Kapalı Çarşıdan da sitayişle bahseder. (Hakkı, Zikreyât Matviyye, 1993: 72)

Yahya Hakkı burada hem konu ile ilgili olarak hem de diğer bazı konularda yine Türkiye'deki hatıralarına dayanarak Dem‘a ve ibtisâme adlı eserinde de bazı şeyler yazdığını söylemektedir: (Hakkı, Dem‘a ve İbtisâme, 1965: 22-26)

Âşıkların birbirleri için zaman zaman kullandıkları "yavrum" kelimesinin hiçbir dilde bulunmadığını söyleyen yazar, dönemin Türkiye'sindeki kız kaçırma olaylarından bahsetmekte ayrıca erkeğin kadına olan hâkimiyetini de dile getirmektedir. Türkiye'de ikametinin üzerinden henüz bir hafta geçmeden kız kaçırma olayları ile ilgili pek çok haber gördüğünü söylemektedir. Ona göre bu kaçırma olayı erkekliğin bir nişanesi olarak görülmektedir. Yazar çok yer gezdiğini ancak Türkiye'de yaşadığı dönemde kadının acımasız erkeklerin kurbanı olduğunu özellikle dile getirmektedir. Bu durumu gördükten sonra eğlence yerlerinde müzik dinleyecek gücünün kalmadığını, insanları özellikle genç kızları umutsuz gördüğünü belirttikten sonra pek çok yerde minberlerde din adamlarının umut dağıttıklarını ifade etmekte Yüksek Kaldırım'daki bir cami imamının hutbede temizlikten bahsederek özellikle esans kullanılmadığı sürece tam temizlik olmayacağını belirtmesinin kendisine çok da itici gelmediğini ifade etmektedir. Bu arada ölülerin defin işlemlerinden de bahseden yazar, apartmanlar arasında hiç kimsenin dönüp de bakmadığı pek çok ölü kemiğinin sağa sola dağıldığını gördüğünü kaydetmektedir. Yazarın mezarlıklar için yapmış olduğu şu değerlendirme oldukça içlidir: "Istanbul'daki mezarlıklar hüzünlü selvi ağaçlarlyla doluydu. Rüzgâr estiğinde yaprakları sanki feryâd ü figan, matem ve inleme seslerine benzer ses çıkarıyordu." (Hakkı, Dem'a ve İbtisâme, 1965: 24)

Bu mezarlıklar arasında en meşhurunun Ebû Eyyûbi'l-Ensâri (Eyüp) mezarlığının olduğunu söylemektedir. Yazar Türkiye'deki ikameti esnasında özellikle İslâmî uyanışı etkileyen XIX. yüzyıl fikir ve siyaset adamlarından Cemâleddin el-Efgânî (1838-1897) (Hayreddin Karaman, 1994: 456-466) ile Mısırlı hatip, gazeteci ve şair Abdullah Nedîm'in (Hulusi Kılıç, 1988: 125-126) kabirlerini çok aradığını ancak bulamadığını dile getirmektedir.

Yazar, iki cami dışında İstanbul'daki camilerin duvarlarının ifade ettiklerinden daha fazla bir şey ifade edemediklerini söylemektedir. Bu iki caminin kalbini etkilediğini ruhunu okşadığını kaydetmektedir. Bu camilerden olan Eyüp camiine gidişini şöyle anlatmaktadır: 
“Galata Köprüsü'nden kalkan gemiye bindim. Gemi Haliç'in durgun sularını yarıyordu. Bugüne kadar Haliç'in bu müzikal bir isimle adlandırılması hususunda yapılan açıklamalardan ikna olmamıştım. Haliç'in kıvrılmasını boynuza benzetmişlerdi. Altına benzetilmesi de orada daima çeşitli mallarla yüklü gemilerle dolu olmasındandı." (Hakkı, Dem‘a ve İbtisâme, 1965: 25)

Ayasofya camiinin eşsiz sanatının güzelliğinden aldığı zevkin bu caminin karşısında uzun uzun durmasına neden olduğunu söyleyen yazar, caminin hala Bizans sanatının bir eseri olarak kabul edilen kilisenin adını taşıdığını ifade etmektedir.

Yazar, daha sonra İstanbul'da birlikte çalıştığı bazı kişilerden de bahseder. (Hakkı, Zikreyât Matviyye, 1993: 73-82) Abdurrahman Hakkı Paşa, Ahmet Remzi, Ahmet Hilmi bunlar arasında yer almaktadır. Konsolos olan Abdurrahman Hakkı Paşa'nın son derece önemli ve titiz bir insan olduğunu söyleyen yazar, konsolosun sabah muayyen bir saatte işine geldiğini, öncelikle gazeteleri gözden geçirerek Türkiye ve Mısır'ı ilgilendiren haberleri seçtiğini söylemektedir. Ahmet Remzi ise konsoloslukta memurdu. Londra'daki Mısır sefaretinden gelmiş ancak yazarın ifadelerine göre İngiltere'nin oldukça etkisinde kalmıştır. Yazar bunlara delil olarak da Ahmet Remzi'nin devamlı surette pipo içmesini, Ingiliz ayakkabısı giymesini vermektedir. Ahmet Hilmi'yi ise tanıdığı en ilginç şahsiyetler arasında görmektedir. Ahmet Hilmi'nin İstanbul'da kısa zamanda Türkçe ve Fransızca öğrendiğini söylemektedir. Tam bu noktada Yahya Hakkı konsoloslukta çalışanlar için önemli bir değerlendirme yapmaktadır:

\footnotetext{
"Tek bir konsoloslukta üç kişinin çalıştığı görülmektedir. Aralarında kötü bir anlaşmazlık varsa hayat çekilmez hale gelir. Bilmiyorum dışardaki Mısırlıların birbirlerini sevmeleri, birlik olmaları, birbirleriyle yardımlaşmaları nasıl kolay gerçekleşebilir. Ahmet Hilmi, Mısır'dan Istanbul'a ziyaretçi geldiği vakit onları alır alışveriş yerlerine götürür, böylece kendisi alışveriş yaptığı zaman büyük bir indirim kazanırdı. Avrupa'nın pek çok Mısır elçiliklerinde ve konsolosluklarında bu tür memurlar bulunmaktadır. Bur durumla ben de karşılaş̧ım. Bize iki müsteşar gelmişti. Onlarla tanıştım ve arkadaş olduk. Bir ara benden ahlaki değerlerimizi uymayan bir şey talep ettiler. Ben de onlara Mısır hükümetinin beni buraya 'k...lık' için değil, konsolos yardımcısı olarak gönderdiğini söyledim ve reddettim." (Hakkı, Zikreyât Matviyye, 1993: 80)
}

Yahya Hakkı, diğer taraftan Sami Rızkullah Semîke, Abdüsselâm Rafet'ten de bahsetmektedir. Özellikle Abdüsselam Rafet'in çok değerli arkadaşlarından ve cana yakın birisi olduğunu, her sabah çalışanlara nükteler söylediğini aktarmaktadır. Yahya Hakkı'nın Abdüsselam Rafet'le ilgili bir hatırası da dikkate değerdir: "Onu evine ziyarete 
gittiğimde yatağının yanında '101 nükte' adlı bir kitap gördüm. Anladım ki nükteleri ezberliyor ve her sabah bize anlatıyordu." (Hakkı, Zikreyât Matviyye, 1993: 81)

Yahya Hakkı, konsolos olarak Abdurrahman Hakkı'dan sonra Ahmet Hakkı'nın tayin edildiğini anlatmaktadır. 1899 senesinde İskenderiye Montaza sarayında doğup 1980 senesinde de İstanbul Ortaköy'de ölmüş ve Mısırlı bir prens olan Prens Muhammed Abdülmünim'in zaman zaman konsolosluğa konsolos Ahmet Hakkı'nın yanına geldiğini ve saatlerce sohbet edip kahkahalar atarak güldüklerini anlatır.

Yahya Hakkı, Abdurrahman Hakkı, Ahmet Hakkı ve kendisinin akraba olmadıklarını da belirtmektedir.

\section{5. İslâm ve Laiklik Arasındaki Türkiye Hakkındaki İntibaları}

Ona göre Türkiye, İslâm tarihinde görülmemiş bir olayı gerçekleştirmiştir. Şeriati uygulayan, bir Şeyhülislamı olan tıklım tıklım dolu camilerinde Kur'ân okunan, tasavvuf tekkeleri bulunan bir ülke nasıl olur da göz açıp kapayıncaya kadar şer'î kanunlarını ilga edip İsviçre kanunlarını uygulayan laik bir devlet haline gelebilir? Nasıl olur da tekkeler kapanır, şer'î mahkemeler kapanır ve Türkiye sanki bir Avrupa devleti haline gelir? Yazarın burada üzerinde durduğu nokta bu değişimin sebebidir.

Konu ile ilgili olarak yazar bir başka eserinde şunları söylemektedir:

“...bütün tekkeler ve daha fazlası kapatılmıştı. Ben iki Türk Mevlevi tekkesinin bulunduğu ülkeden bu ülkeye geldim. ...Bunlardan ilki, Yazma Eserler Kütüphanesi'nin sahibi merhum Ahmet Talat Sarayı'nın karşısında es-Süyûfiyye semtindedir. Diğeri ise kale tarafından Mukattem dağının altında bulunan derin bir mağaranın içindedir." (Hakkı, Dem'a ve ibtisâme, 1965: 16-21)

Onun bu ikameti esnasında edindiği intiba Türk insanının İslâm'a son derece bağlı olduğudur. Ayrıca camilerin sadece erkeklerle değil bayanlarla dolup taştığını söylemektedir. Türkiye'nin bazı köylerini gezdiğini ve bu köylülerin Peygamberî çok sevdiklerini dile getirmektedir. Ancak yazarımız bu peygamber sevgisini aşırı bulduğunu da belirtmektedir. Hatta bu konuda şu ifadeyi kullanmaktadır: "...ilginçtir; Peygamberî öylesine seviyorlar ki bazen bana bu sevgi Allah sevgisinin üzerindeymiş gibi geliyor." (Hakkı, Zikreyât Matviyye, 1993: 83)

Yazara göre Türkiye'de iki şeyin üzerinde durmak önem arz etmektedir. Siyasi açıdan bu ülkede ne oldu? Bu değişiklik nasıl meydana geldi? 
Bilindiği gibi İslâm orduları Avrupa'ya iki yoldan girmiştir. Birincisi doğudan Endülüs'ten gerçekleşmiştir. Bu da tam 500 yıl sürmüştür. Diğeri ise Türkler kanalıyla olmuştur. Türkler, Viyana kapılarına kadar gelmişlerdir. Mısır'ın fethiyle başlayan dönemle de Osmanlı, tüm Müslümanları koruyan bir devlet haline gelmiştir. Yahya Hakkı'nın aşağıdaki ifadeleri bize göre belge niteliğindedir. Pek çok Arap tarihçisinin de kulağına küpe olmalıdır:

\footnotetext{
"Türklerin Arap ırkını ortadan kaldırmak ve Araplara zorla Türkçe öğretmek istediklerine dair söylenenleri bir kenara koyalım. Türkler, hiç Mısırlılara zorla Türkçe öğretmeye teşebbüs ettikleri olmuş mudur? Asla! Türkler kendi ilkokullarında Arapça'yı mecbur kılarken Türkçe'nin Mısırlılara dayatıldığı hiç olmamıştır." (Hakkı, Zikreyât Matviyye, 1993: 83)
}

Yahya Hakkı gibi Osmanlılara zaman zaman insafla bakan araştırmacılara rastlayabiliyoruz. Mesela Mısırlı Dr. Fehmi Şinnâvî'nin şu sözü de son derece önem arz etmektedir: "Günümüz Arap zirvelerinde temel mesele, Israil'e ne kadar boyun eğileceğidir. Eğer Osmanlıya bunun binde biri kadar boyun eğebilseydik, şimdiye kadar elimize geçenlerin milyon katını kazanırdık." (Armağan, 2013: 109)

Bir keresinde İstanbul'dan gemiyle dönerken bazı Yunan adalarının güzelliğini görünce Vapurdan inip bu adaların cazibesini yakından görmek isteyen yazarımız, Midalin (Midilli) ve Serkis (Sakız) adlı adalara çıkar. Bu adalarla Türk toprağı arasındaki mesafe de av teknesiyle yaklaşık bir buçuk saattir. Bir balıkçı teknesine binen yazarımız, Türk kıyısına ulaşır. Burada pek çok otelin bulunduğunu ancak otellerde hiçbir müşterinin olmadığını belirtir. Yazarımız bu otellerden birine girer, otelin sahibi içerde oturmuş nargile içmektedir. Bu zat yazarımıza Türkler ve Yunanlılarla ilgili bazı olaylar anlatarak Yunanların üzüm konusunda oldukça deneyimli olduklarını söyler.

Bu arada Yunanlıların ülkeden çıkarılmalarının asıl sebebinin M. Kemal Atatürk'ün savaş taktiği olduğunu zikrederek şunu ifade eder:

“...onun savaş taktiği Türk ordusu ilerlemeden önce düzensiz gerilla birliklerinin önceden gönderilerek Yunan askerlerinin ve bölgede ikamet etmekte olan Yunan halkının kalbine korku salması sonrasında da Türk ordusunun girilmesi gereken yere girmesidir." (Hakkı, Zikreyât Matviyye, 1993: 87)

Bu noktada Yahya Hakkı önemli bir noktaya temas etmektedir. 
“Italya'nın Anadolu'nun bazı yerlerini, Ingiltere'nin de Istanbul'u işgal ettiğinde tüm Müslümanlardan beklenen Türkiye'nin yanında yer almalarıydı. Ama ne yazık ki, Islâm dünyası Türkiye'nin karşısında yer aldı. Bunun en büyük örneğinin de Mekke Şerifi Hüseyin'in tutumu ve en önemlisi de Ingiliz Lordu McMahon ile olan gizli yazışmalarıydı. Bu gizli yazışmalarda Ingiliz Lordu McMahon, Şerif Hüseyin'e 'Sen Arap'sın, özgür olmalı ve Türklere karşı savaşmalısın', Şerif Hüseyin de Lord'a 'Evet... evet, para göndermelisiniz' diyordu. Hüseyin'in yazmış olduğu her mektup para talebi ile bitiyordu. Kendisine para da gönderiyorlardı." (Hakkı, Zikreyât Matviyye, 1993: 88)

Tam da burada Yahya Hakkı çok önemli bir noktaya daha değinmektedir:

"Üzücü olan Mekke Şerifi Hüseyin'e esir düşen Türklere yapılanlardır. Yakinen biliyorum ki, hapishanede yer altındaki hücre dahi denilemeyecek yerlerde kalıyorlardı. Hicaz'da da Türk esirlere böyle muamele ediliyordu. Diğer yerlerde de durum farklı değildi. Mısır da öyleydi. Mısır ordusu Süveyş kanalını savunmaktan sorumluydu. Burada Mısır askerleriyle Şam ve Filistin'den gelen Türk öncü kuvvetleri arasında çatışmalar çıkmıştı. Göründügü gibi Arap dünyası olduğu gibi Türkiye'nin karşısındaydı."(Hakkı, Zikreyât Matviyye, 1993: 89)

Yahya Hakkı, Mustafa Kemal Atatürk'ün Araplar hakkındaki düşünceleri bahsinde ise onun onlardan pek hoşnut olmadığını aktarmaktadır. (Hakkı, Zikreyât Matviyye, 1993: 89)

Hatta bu durumun herhalde halkı etkilediğini anlatmak için de şöyle bir anısını dile getirir:

"Istanbul'un köylerinden birindeydik. Arapça konuşuyorduk. Yanımızda oturan kişi birden ayağa fırlayıp 'siz Arap mısınız' diyerek sırtını döndü ve arkasındaki darbeleri bize gösterdi." (Hakkı, Zikreyât Matviyye, 1993: 90)

Yahya Hakkı, Mustafa Kemal Atatürk'ün bir Mısırlı diplomatla yaşadığı olayı şöyle nakletmektedir:

"Türkiye her yıl Ekim'de 29 Ekim Cumhuriyet Bayramı kutlanır. Çankaya'da verilen
resepsiyonda resmi elbiselerle kutlamalar olur. Fakat bizim resmi elbisemiz teşrifat
elbisesi ile fesimizdi. Bizim elçilik çalışanlarından Abdülmelik Hamza da fes giyerek
kutlamaya gelmişti. Mustafa Kemal Atatürk ise festen hoşlanmıyordu. Abdülmelik
Hamza'yı karşısında fesli görünce onu yanına çağırarak fesini çıkarmasını ister.
Abdülmelik Hamza çok zor durumda kalır. Çıkarsa mıydı yoksa talebi yerine
getirmeyerek diplomatik bir krize mi sebep olsaydı? Bereket versin sonunda fesi 
çıkararak oradan geçmekte olan bir garsonun elindeki tepsiye koyar ve hemen Mustafa Kemal Atatürk'ün yanından ayrılır. Müșavirimiz Tevfik Silahdar ile ataşemiz Ahmed Remzi'ye göz ile işaret ederek hemen ayrılmalarını ister ve oradan ayrılırlar. Akabinde 1925-1939 yılları arasında Türkiye Dışişleri Bakanlığı yapmış olan Tevfik Rüşü Aras (1883-1972) elçiliğimize gelerek Abdülmelik Hamza'nın gönlünü almak ister ve şöyle der: Atatürk, bu davranışı ile seni kesinlikle küçük düşürmek istemedi. Hava çok sıcaktı, seni bu sıkıntıdan kurtarmak istedi. O, senin böylesi yerlerde hafif şeyler giymeni ve diğerleri gibi davranmanı istedi. Kaldı ki senden başka fes given de yoktu." (Hakkı, Zikreyât Matviyye, 1993: 93)

Fakat Abdülmelik Hamza, Mısır hükümetine olayı iletmeye kararlıdır. Mektubun normal posta ile gitmesi halinde Türk yöneticilerinin bu işi anlayacaklarını tahmin ettiğinden bu iş için Yahya Hakkı'yı Atina'ya gidip mektubu oradan postaya atmakla görevlendirir. Yahya Hakkı da ertesi gün İstanbul'dan bir gemiye binerek Atina'ya varır. Bu olaydan sonra Mısır ile Türkiye ilişkileri uzun bir süre gerginlik yaşar.

Yahya Hakkı, M. K. Atatürk'le ilgili H. C. Armstrong'un (1891-1943) yazmış olduğu Bozkurt adlı kitaptan da bahseder. (Hakkı, Zikreyât Matviyye, 1993: 95)

Enver Sedat'ın (1918-1981) hatıralarından bu kitabın Sedat tarafından okunduğunu anlıyoruz. Yazarın burada verdiği bilgiler arasında Enver Sedat'ın Sudan kökenli babasının Türk generallerine olan hayranlığından dolayı büyük oğluna Enver, küçük oğluna da Talat adını koyduğu da yer almaktadır. (Hakkı, Zikreyât Matviyye, 1993: 95)

Yahya Hakkı bir keresinde Atatürk'ün askeri bir tören sırasında yapmış olduğu konuşmaya tanık olduğunu ve bu konuşmadan da çok etkilendiğini söylemektedir. (Hakkı, Zikreyât Matviyye, 1993: 95)

Aslında yönetim kadrolarını bir tarafa bırakırsak Arap halkının Türk milletine karşı teveccühünün her zaman devam ettiğini rahatlıkla söyleyebiliriz.

\section{Harf Devrimi}

Yahya Hakkı, Mısır'ın ünlü şarkıcılarından Münire el-Mehdiyye'nin (1884-1965) Mustafa Kemal Atatürk ile ilgili ilginç bir anısını aktarmaktadır. Münire el-Mehdiyye bir ara Türkiye'ye gelmiş ve bir konser vermiştir. Bu konsere katılan Atatürk, konserden önce bir sınıf tahtasını salonun bir kenarına koymuş, konser bittikten sonra "Ben Türkçe için kolay Lâtin harfleri tespit ettim. Işte bunlar" (Hakkı, Zikreyât Matviyye, 1993: 97) diyerek harfleri tek tek tahtaya yazmıştır. Yahya Hakkı, "Mustafa Kemal Atatürk'ün bunu Arabi 
harflere ve Arap klasik müziğine karşı olan Münire el-Mehdiyye'nin yanında yapmıştır', demektedir. (Hakkı, Zikreyât Matviyye, 1993: 97)

Yahya Hakkı, "Bizim evimizde köylü hizmetçi bir kadın vardı. Kısa bir zaman içinde Lâtin harfleriyle yazılan Türkçe'yi öğrendiğine şahidim” diyerek (Hakkı, Zikreyât Matviyye, 1993: 98) yeni alfabenin eski alfabeden daha kolay olduğunu ifade etmektedir.

Yahya Hakkı, tam burada "Son derece önemli olan soru şudur." diyerek "Türk kültürüne; şairleri, edebiyatı, büyük kütüphaneleri bakımından Arap edebiyatından geri kalmayan o değerli hazineye ne oldu? Bu anî değişikliğin sonuçları ne olacak? Yeni neslin bu kültürle bağı ne olacak' diye de bir soru sormaktadır.

\section{Yahya Hakkı 1951 Senesinde Ankara'da}

Yahya Hakkı 1951 senesinde tekrar Türkiye'ye geldiğinde farklı bir Türkiye ile karşılaşır. Cumhuriyet döneminin ilk yıllarına nazaran her açıdan daha rahatlamış bir Türkiye profili çizer. Bu sefer Ankara'ya tayin edilen Yahya Hakkı, Adnan Menderes'in Amerika'nın da yardımıyla birçok yol yaptığını ve sayısız ıslahatları devreye soktuğunu belirtir.

Bulunduğu bölgelerde pek çok köyü ziyaret eder. Her gittiği yerde Adnan Menderes döneminin hemen anlaşıldığını dile getirir: "Köylerde yaptığım geziler sırasında yıkılmış ahşap bir köprüden geçtiğimizde 'bu Osmanlı köprüsüdür' betonarme bir köprüden geçtiğimizde ise 'bu Menderes köprüsüdür' derlerdi." (Hakkı, Zikreyât Matviyye, 1993: 176)

1951 senesinde Ankara'ya geldiğinde kendi ifadelerine göre Mısır ile Türkiye arasındaki ilişkilerin ne dostane ne de düşmanca olduğunu belirtir.

Çağrıldığı bazı kutlamalardaki dans ve çalgıları ilginç olarak değerlendiren yazar, Anadolu'da pek çok şehir, kasaba ve köyü gezdiğini ve buralardan pek çok izlenim edindiğini söyler. Gezdiği şehirler arasında Konya, Bursa, İzmir, Erzurum, Sivas, Rize bulunmaktadır.

"Benim arabam yoktu. Fakat o zaman tek kişilik arabalar vardı. Şehir merkezine iner, kahvehanede otururdum. Orada çavuş (Dolmuş ve minibüs duraklarında, dolmuş ve minibüslere yolcu toplayanlara verilen ad) denilen bir görevli vardı. Gelir bize uğrar ve 'gelen bir araba var' derdi. Biz de ona biner giderdik." (Hakkı, Zikreyât Matviyye, 1993: 178) 
Bu gezileri sırasında bazı otellerde kaldığını ve bunların bazılarının pislikten geçilmediğini (?) bazılarının ise idare ettiğini dile getiren yazar, Türklerin çok fakir olduğunu söyler. Şu ifadeleri dönemin insanını anlamamız bakımından oldukça değerlidir.

"Fakir insanların evlerine misafir oldum. Hepsinde İslâmî hassasiyetler gördüm. Müslüman olduğum için beni çok sıcak karşıladılar. Lâiklikten sonra inanılması biraz zor bir durum. Bu şu demektir: Ne yaparsanız yapın, köylünün kalbinden bazı duyguları yok edemezsiniz." (Hakkı, Zikreyât Matviyye, 1993: 178-179)

Ankara'da Yahya Hakkı ile Fuat Köprülü arasında özel bir dostluk peyda olmuştur. Yahya Hakkı'nın eşi de Fuad Köprülü'nün eşi ile yakın arkadaş olmuş ve birbirlerine sık sık ev ziyaretlerinde bulunmuşlardır. Yahya Hakkı, pek çok bakan ve üst yetkilileri sadece tören ve kutlamalarda görmüştür.

Yahya Hakkı, Türkiye'nin kalkınması ile ilgili olarak da şu görüşlere yer vermektedir: Türkiye'nin kendi zamanına kadar ziraat ülkesi olduğunu, ücretlerin çok iyi olmadığını ve bazılarının da çok düşük olduğunu söyler. Eğitimin, lâik sisteme rağmen eski düzene göre yürüdüğünü, okullarda İslâm’la ilgili bir öğrenimin olmadığını, İngilizce'nin her tarafa yayıldığını, yüksek gümrük vergilerinden dolayı üreticilerin sorun yaşadığını, Adnan Menderes'in inşa ettiği yollar sayesinde zirai ürünlerden iyi bir gelir elde edildiğini, ülkenin bu dönemde çok fakir ve memurların maaşlarının kötü durumda olduğunu dile getirir.

Yazar dönemin Türk kadınını ikiye ayırmıştır; diğer yerlerdeki kadınlar gibi köylerde bağ bahçe ve işleriyle uğraşan kadınlar. Diğerleriyle ilgili ise şunları söylemektedir:

\footnotetext{
"Şehirlere gelince buralarda çok çalışan kadın görmedim. Sanki evlerine kapanmışlar, misafir karşılamayı yeğleyip tanışmak istiyorlar. Özellikle yabancı dil biliyorlarsa yabancılarla hemen tanışır ve onlarla yakınlık kurarlar". (Hakkı, Zikreyât Matviyye, 1993: 182)
}

Bazı yemeklerden da bahseden yazar, rakının ve kuru üzümün Türk halkı tarafından çok sevildiğini söylemektedir. Yazar özellikle rakı geleneğini anlatırken "büyük bir üzüntü ile söylemek isterim ki' ifadesini kullanmaktadır.

Türkçe'den Arapça'ya çeviri yapacak düzeye gelen yazar, basını çok iyi takip edebilmektedir. Bazı Türk gazetelerinin Mısır'dan İsrail ile barış yapmasını istediğini de 
kaydeden yazar, o sıralar Türkiye'nin içinde olduğu ve Mart 1951'de Suriye-İsrail sınırında başlayan silahlı çatışmalardan dolayı kurulmuş olması muhtemel uluslararası bir barış komitesinin varlığından bahsetmekte ayrıca Türk komitesinin üyesinin çalıştığı gazetede bu minvalde makaleler yazığını söylemektedir. (Hakkı, Zikreyât Matviyye, 1993: 184)

Adana'da başta Hacı Ömer Sabancı olmak üzere bir grup iş adamı bir araya gelerek bölgedeki pamuk üreticilerini düşünerek onlara finansman desteği sağlamak amacı ile Ocak 1948'de kurulmuş olan Akbank'ın faaliyetlerinden haberdar olan Yahya Hakkı, bu faaliyetlerin Mısır'da da uygulanmasını arzu etmektedir. Adı geçen banka ile ilgili olarak şu ifadelere yer vermiştir:

"Akbank adlı bir bankadan haberdar oldum. Bu bankanın iyi bir proje olduğunu düşünerek her seferinde hazineye müracaat edileceğine su kanalları ve ışıklandırma projeleri konusunda belediyelerin bu konudaki işlerini hızlandırmak için bu projeyi Mısır Hükümeti'ne teklif ettim."

Yazarın görmüş olduğu banka herhalde 14 Temmuz 1950 senesinde ilk İstanbul şubesi olarak Sirkeci'de açılan şube olmalıdır.

\section{Türk Ordusu ile Illgili Değerlendirmesi}

Hükümetlere rağmen asıl gerçek hâkim gücün ordu olduğunu söyleyen yazar, ordudaki subayların hemen hemen hepsinin aynı düşüncede olduklarını, Türkiye ne kadar demokratik ya da başka bir gelişme olursa olsun perde arkasından ülkeyi idare edenin ordu olduğunu belirtir. "Menderes'in asılmasına o kadar üzüldüm ki! Ismet Paşa o dönem hayattaydı ama asılmaması için hiçbir şey yapmadi" demektedir (Hakkı, Zikreyât Matviyye, 1993: 187-188).

"Türkiye üzerinde çalışacaklar için sözümü tekrar ediyorum. Perde arkasından ülkeyi idare eden ordudur. Illke ve inkılaplara son derece bağlıdır. Türkiye laik bir ülkedir. Avrupa aklının peşine takılmıştır. Türkiye'nin Arap ve Müslümanlarla işi olmaz." (Hakkı, Zikreyât Matviyye, 1993: 188)

\section{Türkiye Arap İlişkileri}

Yazar, son zamanlarda (kendi dönemini kastediyor) Türklerle Araplar arasında başlayan yakınlaşma dolayısıyla yapılan siyasi tahlillerden hareketle Orta Doğu'nun kalbinde yer alan Türkiye'nin bu bölgeden vazgeçmesinin mümkün olmadığını söylemektedir. Ayrıca Türkiye'nin NATO'nun bindiği trene bindiği için bu bölgede herhangi olumlu bir rolünün 
olmadığını da belirtmektedir. Diğer taraftan Orta Doğu'da asıl sorunun Araplar ve İsrail arasında olmadığını, sorunun Amerika ve Rusya arasında olduğunu söyleyen yazar, Türkiye ile Rusya arasında eski bir düşmanlık olmadığından Türkiye, siyasetini kendi ihtiyaçlarına göre değil, Amerika ve Rusya mantığına göre belirleyip çizdiğini de ifade etmektedir.

Son olarak Yahya Hakkı; Libya'da atandığı müşavirlik görevine gitmeden önce yakinen tanıdığı Türk edebiyatı tarihçiliğinin ilmi kurucusu, Türkoloji'de yeni ufuklar açmış ilim otoritesi, edip, yazar, siyaset ve devlet adamı olan Fuat Köprülü'yü (Ömer Faruk Akün, 2003: 471-485) ziyarete gider. Ancak hiçbir zaman anlam veremediği bir şey meydana gelir. Köprülü onun karşısında oturtur. Bir süre Yahya Hakkı'ya bakar. Sonra da Köprülü başını önüne eğer ve uzun uzun düşünmeye başlar. Bu arada Yahya Hakkı ne yapacağını bilemez. Sessiz halde durur. Yahya Hakkı'ya göre bunun sebebi, Fuat Köprülü'nün Mısır Hükümeti'ne bir mesaj vermek istediği ancak sonradan vazgeçtiğidir. Yahya Hakkı, ne yapacağını bilemeden Köprülü'nün yanından çıkar. "Diplomatların bazen kafası karışık olur, şaşkınlık içinde olur; bir şey söylemeye çalışır, sonra vazgeçer. Sonunda sessizliğin daha hayırlı olduğuna karar verir." diyerek hatıralarına son verir. (Hakkı, Zikreyât Matviyye, 1993: 189)

\section{Kaynakça}

Musiki Dergisi. (2019, 9 24). Retrieved from musikidergisi.net: musikidergisi.net/?p=494 Armağan, M. (2013). Satılık Imparatorluk. İstanbul.

Hakkı, Y. (1965). Dem'a ve Ibtisâme. Kahire.

Hakkı, Y. (1993). Zikreyât Matviyye. Kahire.

Hayreddin Karaman, E. C. (1994). DiA X.

Hulusi Kılıç, A. N. (1988). DiA I.

Kocak, P. D. (2003). Münir Nureddin Selçuk'un Türk ve Arap Müziğindeki Yeri.

Cumhuriyetimizin 80. Yılında Müzik Sempozyumu (pp. 130-137). İnönü Üniversitesi. Ömer Faruk Akün, M. F. (2003). DIA XXVIII. 